DEVELOPMENTAL AND COMPARATIVE IMMUNOLOGY, Vol. 3, pp. 23-36, 1979. 0145-305X/79/010023-14\$02.00/0 Printed in the USA.

Copyright (c) 1979 Pergamon Press Ltd. All rights reserved.

\title{
A COMPARATIVE APPROACH TO SECONDARY AMYLOIDOSIS
}

\section{MINIREVIEW}

E. GRUYS

Institute of Veterinary Pathology

State University Utrecht

Utrecht, The Netherlands

ABSTRACT In various species including phylogenetically lower animals, the pathological protein amyloid has been found. The characteristics of amyloid depend upon the $\beta$ pleated structure of its fibrils. Various groups of amyloid can be distinguished based on the chemical properties of the fibrils which reveal a different major protein in each group: secondary amyloid, amyloid of immunoglobulin origin, APUDamyloid, senile cardiac amyloid, and amyloid-like substances. In secondary amyloid, the major protein is protein AA which is related to the serum protein SAA. There is a relationship between induced secondary amyloid and the immune system, especially impairment of $T$ cells and dysfunction of macrophages. The formation of protein AA containing amyloid will depend upon prolonged elevation of SAA levels and the extrusion of lysosomal enzymes from RE cells. The physiological relationship between SAA and the immune system, which it depresses, is unclear.

\section{INTRODUCTION}

Amyloidosis is a well known pathological change in vertebrates, characterized by extracellular deposits of variable amounts of a histologically homogeneous and biologically inert, proteinaceous material. As a consequence of these deposits, cell function is compromised or fails and clinical disease results. The name "amyloid" was given to the material, after Virchow (113) described its chemical composition as cellulose-1ike and comparable to the amyloid encountered in botany (4). Amyloid is composed of rigid nonbranching fibrils (the amyloid fibrils), which are randomly arranged and occur in extracellular groundsubstances. Amyloid fibrils may also occur as parallel strands. The fibrils are of undetermined length and have a diameter of about $75-150 \AA$ (Table I). 
TABLE I

The diameter of purified and negatively stained amyloid fibrils.

\begin{tabular}{llc} 
species & diameter in $\AA$ & references \\
man & $40-80$ & 38 \\
& $70-100$ & 21 \\
& 80 & 42 \\
cattle & $129-157$ & 42 \\
hamster & 146 & 42 \\
\hline
\end{tabular}

The fibrils are composed of two intertwined filaments $(45,78)$. Despite a variable chemical composition in different amyloid groups, the fibrils have a similar molecular structure when examined by $x$-ray diffraction and infrared spectroscopy: the $B$ pleated sheet structure (38).

The reason for presenting this review of amyloid to comparative immunologists is the link between amyloid and the immune system in the two major amyloid groups: secondary amyloid and amyloid of immunoglobulin origin. A comparative study in phylogenetically diverse animals, especially of secondary amyloid, can reveal unknown mechanisms which are basic to its pathogenesis.

\section{CHARACTERISTICS}

Characteristics of amyloid, such as congophilia with typical green birefringence in polarized light and its resistance to proteolysis (38) and autolysis (31), result from the $\beta$ pleated molecular structure. In this arrangement, the (poly)peptide layers are more closely (4.75 $\AA$ ) linked to each other by. hydrogen bonds, than in the $\alpha$ helix or triple helix configuration of other fibrillar proteins. Neutral and acidic mucopolysaccharides occur between the amyloid fibrils and are adsorbed to them (119). Moreover, substances from connective tissue e.g. collagen and basement membrane materials, lipids and serum proteins (e.g. fibrinogen, immunoglobulin proteins, complement factors) occur in varying quantities (67). For human amyloid, many studies have been performed to elucidate the role of a $95 \AA$ pentagonal structure, the plasma (P) component or protein AP $(73,102)$, extractable from amyloid-containing tissues. This protein is identical to the protein $\mathrm{C}_{1} \mathrm{t}(84,60,69)$, thought to be a part of the complement system, although there is still controversy (81). Its Ca-dependent affinity for polyanions might clarify its presence in amyloid (83).

When subjected to various histochemical procedures, most staining methods reveal variable results. Only reactions like Congo red for the B pleated fibrillar proteins will be specific. Wolman's standardized toluidine blue method (with red birefringence) will also react with these fibrillar proteins (22). Iodine binding appears to form a complex with a component in a pepsin-1abile glycoprotein of the interfilamentous matrix of amyloid fibrils (22), Other widely used staining methods e.g. thioflavin with fluorescence and toluidine blue with metachromasia and yellow birefringence, react for acidic mucopolysaccharides and are less specific (119, $107,108,22)$. To distinguish between protein AA-containing and noncontaining amyloid (see below), both staining methods of Wright et al (120) using primary oxydation with potassium permanganate prior to the Congo red stain are recommended for several species (40). 


\section{CLASSIFICATION}

Amyloid can be classified into various groups, which in most instances depend upon clinical parameters or its deposition pattern. The basic division is: I. Secondary amyloid, accompanies disease such as chronic infections or rheumatic disease, and can be induced in laboratory mammals by repeated injections of various substances $e . g$. casein or endotoxin; it shows a "typical" distribution pattern (kidney, liver, spleen); II. Primary amyloid, is not associated in most cases with a primary disease and is characterized by an "atypical" distribution pattern (tongue, heart; cerebral vessels).

After purification of amyloid fibrils, best performed according the method of Pras et al (86), four groups have been found each of which contains a different major protein component. The protein of each group has its own precursor. a. In secondary amyloid, also called amyloid of unknown origin (36) the major protein, protein $\mathrm{AA}$, is a unique component showing no homology with any known iminunoglobulin nor with any protein so far identified. It is similar in different patients and is homologous in various species (man, monkey, mink, mouse, guinea pig, duck $(102,49,32,33,10)$ rabbit (2) and cattle $(40)$ ). Human and monkey protein AA are most nearly identical and consist of 76 amino acid residues and have a molecular weight of about $8500(68,48)$. Murine protein AA (103) and our bovine protein AA (40) which have a molecular weight of about 10,000, after hydrolysis, showed an amino acid analysis $(92,40)$ similar to human protein $A A$ and that of other species. Protein AA shows immunological cross reactivity with a serum $\alpha$ globulin, SAA, which is associated with high density lipoprotein (10) and whose serum levels fluctuate in a manner analogous to acute-phase reactants $(90,74,75,1,100)$. SAA has a molecular weight of $100,000-200,000$ Daltons. Under acidic conditions a low molecular weight protein of 12,500 - 15,000 Daltons can be obtained from SAA, the SAAL $(51,104)$. SAAL has a $\mathrm{NH}_{2}$-terminal amino acid sequence identical with that of protein AA $(100,101,91)$ and is believed to be the precursor of protein AA. Other constituents of amyloid fibrils not containing protein AA will be components derived from normal tissue (50). b. A large proportion of the "primary" amyloid group and the amyloid of myeloma patients is derived from immunoglobulin proteins and is called amyloid of immunoglobulin origin (36). From the amyloid fibrils in these cases, a major protein has been isolated which differed in each patient and was immunologically related to the paraprotein of the same patient. Moreover chemical homology has been found (amino acid composition, $\mathrm{NH}_{2}$-terminal sequence studies) with light chain proteins ( $k$ and $\lambda$ ) from the monoclonal paraprotein, especially its variable part (38). The immunoglobulin origin of these fibrils was favoured since the amyloid-like $\beta$ pleated fibrils were created in vitro in several laboratories by mild proteolytic digestion of Bence-Jones proteins (38). In vivo formation of fibrils will occur by lysosomal cleavage of the paraprotein in RE-cells $(36,64)$, but 1ysosomes may also form in plasma cells of myeloma patients (66).

c. APUD-amyloid. In some cases of the primary amyloid group localized amyloid deposits occur in endocrine glands of the APUD-series (82) and tumours of these glands. Studies on insular pancreatic amyloid and amyloid in medullary thyroid carcinomas indicate that this type of amyloid originates from polypeptide hormone-related proteins of these glands (82, $116,23,109)$. Using acidification or proteolytic enzymes, it has been possible to create amyloid-1ike $\beta$ pleated fibrils from insulin, glucagon and other APUD-hormones $(37,72,62)$. Differing from other types of amyloid, in . the APUD-amyloid, tryptophan is lacking $(82,23,40)$ and tyrosine is present in only smali quantities (115). By means of electron microscopy the fibrils 
may be taller than in other types of amyloid (117).

d. Senile amyloid. Most cases of senile amyloid which occur as primary amyloid during old age, are categorized in one of the former three groups. Senile cerebral amyloid in LM- and EM-immunochemical studies contains immunoglobulins near the area of amyloid fibrils $(53,54)$. This type of amyloid has much in common histochemically with APUD-amyloid (85). From senile cardiac amyloid using isolated amyloid fibrils a unique protein: protein A has been found (118).

e. In addition to these four groups of amyloid, amyloid-like or related fibrils can be found in the "calcifying odontogenic tumour" $(80,15,35)$ and in the corpora amylacea of several epithelial organs (but not in the corpora amylacea of the brain, 106,96). Human prostatic corpora amylacea (46) and corpora amylacea of the bovine mammary gland (87) like those of other species (rat,9) are well known examples. Whether these proteins are categorized in one of the former groups, still must be determined. In the mammary corpora amylacea, positive findings for tryptophan (9) excludes the APUD-group.

\section{THE RELATIONSHIP OF INDUCED SECONDARY AMYLOIDOSIS TO THE IMMUNE SYSTEM}

Several groups of investigators have made comprehensive studies of immunological phenomena associated with induced amyloidosis, mostly using mice and guinea pigs, not rats, since in this species amyloidosis is rare and unreproducable (39); in most cases splenic amyloidosis has been studied. Regarding humoral immunity ( $B$ cells), between amyloid deposits and the localization of plasma cells, no relation has been found (47). Amyloidosis occurs in human patients and in mice with hypogammaglobulinaemia (3). Antibody production against various antigens is unchanged $(20,6)$, but increase of $B$ cell activity has been found in studies of antibody dependent cytotoxity (121). In cell-mediated immunity ( $T$ cel1s), there is a correlation between impaired $\mathrm{T}$ cell function and amyloid (19). In nude mice and thymectomized ones, amyloid can be induced by injecting casein (47). During the first phase after beginning casein injections, $T$ cells increase in the spleen (the first or pyroninophilic phase of Teilum, 110). During the predeposit phase and the deposit phase of amyloid, the number of pyroninophilic cells decreases (47). Daily injections of thymosin restored $T$ cell function and reduced the incidence of casein-induced amyloidosis (93), suggesting thymic involvement. In casein induced amyloidosis, mice and guinea pigs became tolerant for casein $(14,16,17,18)$ and BCG-injections exert a protective influence against amyloidosis $(122,47)$, further evidence associating it with cell-mediated immunity.

Regarding macrophages, during amyloid induction, after the pyroninophilic phase, a second phase, the predeposit phase is characterized by an increase of PAS-positive macrophages in perifollicular areas of the spleen (110). During this phase, carbon clearance (47) and mitogen induced cellular cytotoxicity was elevated (121). At the onset of amyloid deposition, the macrophage activity decreased $(47,121)$. In the predeposit phase in mice, the first amyloid occurred in macrophages, and if spleens were explanted in vitro, there was an increase of intracellular amyloid masses. Moreover, in the supernatant, amyloid-related low molecular weight proteins were observed $(6,7,8)$. The formation of amyloid fibrils in lysosomes of macrophages by cleavage of precursors has been proposed (36). In this context the finding of parallel aligned intralysosomal amyloid fibrils in macrophages in induced murine amyloidosis was explained as formation (99). 
Phagocytosis should result in a random pattern of intravacuolar amyloid fibrils $(98,52)$. In induced phagocytosis of amyloid, however, in an autogenous in vivo model using murine amyloid (111) and in xenogenous models with human (76) and bovine amyloid (44), vacuoles were found containing parallel fibrils. Moreover, in induced amyloidosis of hamster liver, during the predeposit phase, no intracellular amyloid fibrils occurred (41). After enzyme-histochemical LM and EM analyses however, activity of lysosomal enzymes of sinusoidal lining cells (acid phosphatase, $B$ glucuronidase,

$\beta$ glucosaminidase) has been found in extracellular deposits of amyloid (41). After recovery from the induction system, regression of the amyloid masses has resulted from phagocytosis $(30,34)$. In some cases, glomerular amyloidosis of the kidney, however, should increase (30).

\section{AMYLOID ENHANCING FACTOR (AEF), AMYLOID INDUCING FACTOR (AIF) AND SAA}

Induced amyloidosis can be accelerated by injecting extracts from amyloid containing tissue, splenic cultures from mice with amyloid or their supernatants $(63,58,59)$. Splenic tissue of pretreated mice implanted in dialysis bags will also enhance amyloid induction (61). The enhancing influence of splenic cells from pretreated donors might depend upon the transfer of antigen-RNA complexes (AEF) (47). Moreover, injecting splenic cells from normal donors enhanced amyloidosis (5). Splenic suspensions and splenic nuclear fractions from pretreated donors induced amyloidosis in recipients without amyloid inducing treatment, especially after subsequent immunosuppressive treatment. In these cases, amyloid induction should result from an antigen-DNA complex (AIF) which influences protein synthesis by macrophages (47).

The significance and relation of substances AEF and AIF to SAA are still unknown. They may influence the production or release of SAA(L) and/or the release of lysosomal enzymes from RE-cells, which both are required for the formation of secondary amyloid. Because: a. elevation of SAA levels alone does not result in amyloidosis $(12,51)$, b. substances from leucocytes stimulate amyloid formation (65), c. vascular permeability is increased prior to amyloid deposition $(94,95,97)$, d. the major non-protein AA fraction of secondary amyloid fibrils contains normal tissue proteins (50) and $e$. the activity of lysosomal enzymes has been found in newly formed amyloid without the finding of intralysosomal amyloid prior to amyloidosis in our hamsters (41), the proposed pathogenesis of secondary amyloid involves extracellular conversion of SAA after leakage from lysosomal enzymes. Except for precursor of amyloid, SAA probably is a normal protein regulating immunereactivity, because it contains immunosuppressive potencies (11). References concerning the origin of SAA are controversial: formation in macrophages has been proposed (8), and antigenic cross reactivity with fibroblasts $(70,71,79)$ and plasma cells $(114)$ has been described. Moreover, the liver in which relatively large quantities of SAA are found (75) might be its origin, just as it is the site of origin of many other acute-phase reactants.

\section{THE INCIDENCE OF AMYLOIDOSIS IN VARIOUS SPECIES}

Spontaneous amyloidosis is a common finding in man and many other mammalian species. In some species (e.g. sheep, goat and rat) amyloid is rare (57), whilst in others, it has a high incidence (e.g. cattle, 43). 
Since the review of Jakob (57) several incidental findings also concerning other species, have been published. The second group in which amyloidosis commonly occurs is birds, especially in the group of ducks, geese and swan, Anatidae $(88,89,26,27,29,55,56,77,105)$. In phylogenetically lower groups, reports of amyloidosis are rare. In tortoises an "epizooty" has been described (112) and in snakes it has been found (28). Moreover in the earthworm, Lumbricus terrestris, congophilic degeneration has been found after prolonged captivity (24), and in the honey bee, Apis mellifera, amyloidosis of the queens receptaculum seminis has been described (13).

In domestic species, evident strain differences exist between the incidence of spontaneous amyloidosis and the resistance to inducing agents. In nearly all cases, the type of amyloid in the sense of classification, given above, is unknown and many have been described as primary. The finding of protein AA antigen in the different types of bovine renal amyloidosis (40), may indicate that protein AA - (secondary) amyloid can have a higher incidence than expected. Studies of canine cases with the staining methods after Wright et. al. (120) showed that also in this species secondary amyloid occurs most frequently (unpublished results).

\section{CONCLUSION}

The characteristics of amyloid depend upon the $\beta$ pleated structure of the amyloid fibrils. In spite of this structure, the chemical composition varies in different groups of amyloid: secondary amyloid containing protein AA, amyloid of immunoglobulin origin, APUD-amyloid, senile cardiac amyloid, and amyloid-like substances. In amyloid of immunoglobulin origin, the relationship to the immune system is clear. In secondary amyloid, containing protein $A A$, a relationship to the acute-phase reactant SAA does exist, although the physiologic role of this protein and its relationship to the immune system is still unclear. However, many investigations have shown comprehensive changes in the immune system, especially of $T$ cells and macrophages. The formation of amyloid fibrils will depend upon: a. prolonged elevation of SAA levels (the amyloidogenic protein) b. extrusion of lysosomal enzymes. The finding of parallel intralysosomal amyloid fibrils can be explained by phagocytosis. The pathogenesis of APUD-amyloid, senile amyloid and amyloid-like substances, is less clear than the former groups. Amyloidosis is a common pathological finding in mammals and birds and it has been described in reptiles. Amyloid may also occur in the earthworm, Lumbrious, and in certain insects. Since invertebrates and fishes, amphibians and reptiles possess immune capabilities (25), a comparative study of amyloidosis in phylogenetically lower animals may contribute to elucidating the evolutionary role of the immune system in secondary amyloidosis.

\section{REFERENCES}

1. ANDERS, R.F., NORDSTOGA, K., NATVIG, J.B. and HUSBY, G. Amyloid-related serum protein SAA in endotoxin-induced amyloidosis of the mink. J. Exp. Med. 143, 678, 1976.

2. ANDERS, R.F., NATVIG, J.B., SLETTEN, K., HUSBY, G. and NORDSTOGA, K. Amyloid-related serum protein SAA from three animal species: comparison with human SAA. J. Immunol. 118, 229, 1977. 
3. ANDERSON, R.E. Amyloidosis in germiree mice. Am. J. Pathol. 65, 43, 1971.

4. ATERMAN, K. A historical note on the iodine-sulphuric acid reaction of amyloid, Bistochem. 49, 131, 1976.

5. AXELRAD, M., KISILEVSKY, R. and BESWETHERICK, S. Acceleration of amyloidosis by syngeneic spleen cells from normal donors. Am. J. Pathol. $78,277,1975$.

6. BAUMAL, R., ACKERMANN, A. and WILSON, B. Immunoglobulin biosynthes is in myeloma-associated and casein- and endotoxin-induced murine amyloidosis. J. ImmmoZ. 114, 1785, 1975.

7. BAUMAL, R., PASS, E. and WILSON, B. Casein-induced murine amyloidosis: amyloid and immunoglobulin production and proliferative capacity of splenocytes. In: Immone reactivity of lymphocytes. M. Feldman and A. Globerson. Plenum publishing corporation, New York, 1976, p. 679.

8. BAUMAL, R. and WILSON, B. An in vitro tissue culture system for studying amyloidogenesis. Am. J...Pathol. 86, 32 a (abstract), 1977.

9. BEEMS, R.B., GRUYS, E. and SPTT, B.J. Amyloid in the corpora amylacea of the rat mammary gland. Vet. Pathol. 15, 347, 1978.

10. BENDITT, E.P. and ERIKSEN, N. Amyloid protein SAA is associated with high density lipoprotein from human serum. Proc. NatZ. Acad. Sci. U.S.A. $74,4025,1977$.

11. BENSON, M.D., ALDO-BENSON, M.A., SHIRAHAMA, T., BOREL, Y. and COHEN, A.S. Suppression of in vitro antibody response by a serum factor SAA in experimentally induced amyloidosis. J. Exp. Med. 142, 236, 1975.

12. BENSON, M.D., SCHEINBERG, M.A., SHIRAHAMA, T., CATHCART, E.S. and SKINNER, M. Kinetics of serum amyloid protein $A$ in casein-induced murine amyloidosis. J. Clin. Invest. 59, 412, 1977.

13. BORCHERT, A. Schädigungen der Bienenzucht durch Krankheiten, Vergiftungen und Schädlingen der Honigbiene. Hirzel, Leipzig, 1974, p. 227.

14. BRICETTI, A.B., CATHCART, E.S. and COHEN, A.S. Casein-induced experimental amyloidosis. II Lymphocyte transformation in preamyloidotic and amyloidotic guinea pigs. Path. Microbiol. Scand. A. Sup., 233, 162, 1972.

15. BUCHNER, A. and DAVID, R. Amyloid-like material in odontogenic tumors. J. Oral. Surg. 34, 320, 1976.

16. CATHCART, E.S., MULLARKEY, M. and COHEN, A.S. Amyloidosis an expression of immunological tolerance. Loncet (2), 639, 1970.

17. CATHCART, E.S., MULLARKEY, M. and COHEN, A.S. Cellular immunity in casein-induced amyloidosis. Immunol. 20, 1001, 1971.

18. CATHCART, E.S., RODGERS, O.G. and COHEN, A.S. Amyloid-inducing factor and immunological unresponsiveness. Ann. Rheum. Dis. 31, 303, 1972. 
19. CATHCART, E.S., SCHEINBERG, M.A. and BENNETT, M. Amyloidosis and agerelated phenomena in casein-treated mice. Fed. Proc. 33, 3109, 1974.

20. CLAESON, M.H. and HARDT, F. Induction of amyloidosis in germfree NMRI mice after prolonged stimulation with sterilized casein. Clin. Exp. Irmonol. 11, 277, 1972.

21. COHEN, A.S. and SHIRAHAMA, T. Electron microscopic analysis of isolated amyloid fibrils from patients, with primary, secondary, and myelomaassociated disease. Israel. J. Med. Sci. 9, 849, 1973.

22. COOPER, J.H. Selective amyloid staining as a function of amyloid composition and structure. Histochemical analysis of the alkaline Congo red, standardized toluidine blue, and iodine methods. Lab. Invest. 31, 232, 1974.

23. COOPER, J.H. Histochemical properties of pancreatic-insular amyloid. Lab. Invest. 32, $421,1975$.

24. COOPER, E.L. and BACULI, B.S. Degenerative changes in the annelid Lumbricus terrestris. J. Gerontol. 23, 375, 1968.

25. COOPER, E.L. Comparative Immonology. Prentice Hall, Englewood Cliffs, New Jersey, 1976, p. 338.

26. COWAN, D.F. Avian amyloidosis. I. General incidence in zoo birds. Path. Vet. 5, 51, 1968.

27. COWAN, D.F. Avian amyloidosis. II. Incidence and contributing factors in the family Anatidae. Path. Vet. 5, 59, 1968.

28. COWAN, D.F. Disease of captive reptiles. J. Am. Vet. Med. Ass. 153, 848, 1968.

29. COWAN, D.F. and JOHNSON, W.C. Amyloidosis in the white Pekin duck. I. Relation to social environmental stress. Lab. Invest. 23, 551, 1970.

30. DELELLIS, R.A., RAM, S.J. and GLENNER, G.G. Amyloid IX. Further kinetic studies on experimental murine amyloidosis. Int. Arch. AlZergy, 37, 175, 1970.

31. DREHER, R. and VANDRE, F. Amyloid unter dem Einfluss der Autolyse. Beitr. Path. 145, 256, 1972.

32. ERIKSEN, N., FOWLER, S. and ERICSSON, L.H. Origin of amyloid protein A. Fed. Proc. 33, 1563, 1974.

33. ERIKSEN, N., ERICSSON, L.H., PEARSALL, N., LANGUNOFF, D. and BENDITT, E.P. Mouse amyloid protein AA: homology with nonimmunoglobulin protein of human and monkey amyloid substance. Proc. NatI. Acad. U.S.A. 73, 964 , 1976.

34. FIELDS, M., POLLIACK, A. and LAUFER, A. Resorption of amyloid and enzymatic studies in amyloidosis. Israel. J. Med. Sci. 9, 875, 1973. 
35. FRANKLIN, C.D. and PINDBORG, J.J. The calcifying epithelial odontogenic tumor. A review and analysis of 113 cases. Oral Surg. 42, 753, 1976.

36. GLENNER, G.G., FERRY, W.D. and ISERSKY, C. Amyloidosis: Its nature and pathogenesis. Sem. Hemat. 10, 65, 1973.

37. GLENNER, G.G., EANES, E.D., BLADEN, H.A., LINKE, R.P. and TERMINE, J.D. $B$ Pleated sheet fibrils. A comparison of native amyloid with synthetic protein fibrils. J. Histochem. Cytochem. 22, $1141,1974$.

38. GLENNER, G.G. and PAGE, D.L. Amyloid, amyloidosis and amyloidogenesis. Int. Rev. Exp. Pathol. 15, 1, 1976.

39. GREEN, C.J. Amyloidosis as an incidental finding in rats on experiment. Lab. Anim. 8, 99, 1974.

40. GRUYS, E. to be published. Abstract of lecture held at the 27 conference of the European Community of Veterinary Pathologists in Vienna, May 1978, will be published as: New findings in bovine amyloid, Vet. Pathol.

41. GRUYS, E., TIMMERMANS, H.J.F. and van Ederen, A.M. The deposition of amyloid in the liver of hamsters. Lab. Anim. in press.

42. GRUYS, E. and RUINEN, L. Vergleichung von Amyloidfibrillen bei Mensch, Rind, und Hamster. Fortschr. Med. 96, 1978, in press.

43. GRUYS, E. Amyloidosis in the bovine kidney. Vet. Sci. Com. 1, 265, 1977.

44. GRUYS, E. and CASTANO, M. Parallel intralysosomal amyloid fibrils, a possible result of phagocytosis. Vet. Pathol. 14, 407, 1977.

45. GUEFT, B., KIKKAWA, Y. and HIRSCHL, S. An electron-microscopy study of amyloidosis from different species. In: Amyloidosis. E. Mandema, L. Ruinen, J.H. Scholten, A.S. Cohen. Excerpta Medica Foundation, Amsterdam, 1968, p. 172.

46. GUEFT, B. The X-ray diffraction pattern of prostatic corpora amylacea. Acta. Path. Microbiol. Scand. A. Sup. 23, 132, 1972.

47. HARDT, F. and RANLOV, P. Transfer amyloidosis. Int. Rev. Exp. Pathol. 16, $273 ; 1976$.

48. HERMODSON, M.A., KUHN, R.W., WALSH, K.A., NEURATH, H., ERIKSEN, N. and BENDITT, E.P. Amino acid sequence of monkey amyloid protein A. Biochem. $11,2934,1972$.

49. HUSBY, G., NATVIG, J.B., SLETTEN, K., NORDSTOGA, K. and ANDERS, R.F. An experimental model in mink for studying the relation between amyloid fibril protein AA and the related serum protein SAA. Scand. J. Immmol. $4,811,1975$.

50. HUSBY, G. and SLETTEN, K. Structural similarities between a protein extracted from normal tissues and a component of amyloid fibrils. Acta Pathol. Miarobiol. Scand. C, 85, 153, 1977. 
51. IGNACZAK, T.F., SIPE, J.D., LINKE, R.P. and GLENNER, G.G. Immunochemical studies on the nature of the serum component (SAA) related to secondary amyloidosis. J. Lab. Clin. Med. 89, 1092, 1977.

52. ISHIHARA, T. and UCHINO, F. Pathological studies on amyloidosis. Amyloid formation and resorption in Kupffer cell. Rec. Adv. RES Res. 15, 145, 1975.

53. ISHII, T., HAGA, S. and SHIMIZU, F. Identification of components of immunoglobulins in senile plaques by means of fluorescent antibody technique. Acta Neuropath. 32, 157, 1975.

54. ISHII, T. and HAGA, S. Immuno-electron microscopic localization of immunoglobulins in amyloid fibrils of senile plaques. Acta Neuropath. $36,243,1976$.

55. JAKOB, W. and HILGENFELD, M. Vergleichende Untersuchungen über das färberische Verhalten amyloider, fibrinoider und hyaliner Ablagerungen in der Gefässwand verschiedener Säugetiere und vöge1. Path. Vet. 6, $30,1969$.

56. JAKOB, W., KRIEG, K. and HILGENFELD, M. Vergleichende Untersuchungen über das histochemische Verhalten amyloider, fibrinoider und hyaliner Ablagerungen in der Gefässwand verschiedener säugetiere und vögel. Path. Vet. 6, 557, 1969.

57. JAKOB, W. Spontaneous amyloidosis of mammals. Vet. Pathol. 8, 292, 1971.

58. JAKOB, W. and HILGENFELD, M. Beschleunigte Amyloidbildung bei Mäusen durch Organmaterial von Tieren mit Spontanamyloid. Zbl. Allg. Path. 116, 94,1972 .

59. JAKOB, W., HILGENFELD, M. and KARASEK, E. Beschleumigte Amyloidbildung bei Mäusen durch Milzzellkulturen. Exp. Path. 6, 141, 1972.

60. KATZ, A., WEICKER-THORNE, J. and PAINTER, R.H. The relationship of a serum protein $C_{1} t$, to a common nonfibrillar constituent of amyloid ( $P$ component) as revealed by immunohistochemical studies. Am. J. Pathol. $88,679,1977$.

61. KEDAR, I., BLEIBERG, I. and SOHAR, E. Stimulation of murine amyloidosis by a dializable product from pretreated donors. Brit. J. Exp. Path. 56, $244,1975$.

62. KEDAR, I., RAVID, M. and SOHAR, E. In vitro synthesis of amyloid fibrils from insulin, calcitonin and parathormone. Isr. J. Med. Sci. 12, 1137 , 1976.

63. KEIZMAN, I., RIMON, A., SOHAR, E. and GAFNI, J. Amyloid accelerating factor. Purification of a substance from human amyloidotic spleen that accelerates the formation of casein-induced murine amyloid. Acta Path. Microbioz. Scand. A. Sup. 233, 172, 1972.

64. KISILEVSKY, R., AXELRAD, M., BRUNET, S. and RICHARDS, M. Effects of amyloid induction on plasma protein turnover and its implication. Am. J. Pathol. 83, 299, 1976. 
65. KISILEVSKY, R., AXELRAD, M., CORBETT, W., BRUNET, S. and SCOTT, F. The role of inflammatory cells in the pathogenesis of amyloidosis. Lab. Invest. $37,544,1977$.

66. KJELDSBERG, C.R., EYRE, H.J. and TOTZKE, H. Evidence for intracellular amyloid formation in myeloma. Blood, 50, 493, 1977.

67. LETTERER, E. History and development of amyloid research. In: AmyZoidosis. E. Mandema, L. Ruinen, J.H. Scholten, A.S. Cohen. Excerpta Medica Foundation, Amsterdam 1968, p. 3.

68. LEVIN, M. The amino acid sequence of a major non-imnunoglobulin component of some amyloid fibrils. J. Clin. Invest. 51, 2773, 1972.

69. LEVO, Y., FRANGIONE, B. and FRANKLIN, E.C. Amino acid sequence similarities between amyloid $P$ component, $C_{1} t$ and CRP. Nature, 268, 56, 1977.

70. LINDER, E., ANDERS, R.F. and NATVIG, J.B. Connective tissue origin of the amyloid-related protein SAA. J. Exp. Med. 144, 1336, 1976.

71. LINDER, E., LEHTO, V.P., VIRTANEN, I., STENMAN, S. and NATVIG, J.B. Localization of amyloid-related serum protein SAA-1ike material to intermediate $(10 \mathrm{~nm})$ filaments of cultured human embryonal fibroblasts. J. Exp. Med. 146, 1158, 1977.

72. LINKE, R.P., EANES, E.D., TERMINE, J.D., BLADEN, H.A. and GLENNER, G.G. Formation of amyloid-like fibrils from insulin and glucagon in vitro. In: Amyloidosis. 0. Wegelius and A. Pasternack. Academic Press, London, 1976, p. 371 .

73. MANDEMA, E., RUINEN, L., SCHOLTEN, J.H. and COHEN, A.S. AmyZoidosis. Excerpta Medica Foundation, Amsterdam, 1968.

74. MCADAM, K.P.W.J. and SIPE, J.D. Murine model for human secondary amyloidosis: Genetic variability of the acute-phase serum protein SAA response to endotoxin and casein. J. Exp. Med. 144, 1121, 1976.

75. MCADAM, K.P.W.J. and SIPE, J.D. Serum precursor of murine amyloid protein: An acute phase reactant in responce to polyclonal B cell mitogens. Fed. Proc. 35, 1650, 1976.

76. MOHR, W., PAULINI, K., BENEKE, G. and SCOMAZZONI, G. Resorption of amyloid. Pathol. Microbiol. 41, 240, 1974.

77. MORIGUCHI, R., IZAWA, H, and SOEKAWA, M. Histopathology of spontaneous amyloidosis in duck. Kitasato Arch. Exp. Med. 47, 77, 1974.

78. NAESER, P. and WESTERMARK, P. Amyloidosis in ageing obese-hyperglycemic mice and their lean littermates. Acta Path. Microbiol. Scand. $A, 85,761,1977$.

79. NATVIG, J.B., LINDER, E. and ANDERS, R.F. Evidence for connective tissue origin of the amyloid related serum protein SAA. In: Nonarticular forms of rheumatoid arthritis. T.E.W. Feltkamp. Stafleu, Leiden, 1977, p. 172 . 
80. PAGE, D.L. WEISS, S.W. and EGGLESTON, J.C. U1trastructura1 study of amyloid material in the calcifying epithelial odontogenic tumor. Concer, 36, 1426, 1975.

81. PAINTER, R.H. Evidence that $C_{1} t$ (amyloid P-component) is not a subcomponent of the first component of complement $\left(C_{1}\right)$. J. Immunol. 119, $2203,1977$.

82. PEARSE, A.G.E., EWEN, S.W.B. and POLAK, J.M. The genesis of APUDamyloid in endocrine polypeptide tumours: Histochemical distinction from immunamyloid. Virchows. Arch. $B, 10,93,1972$.

83. PEPYS, M.B., DASH, A.C., MUNN, E.A., FEINSTEIN, A., SKINNER, M., COHEN, A.S., GEWURZ, H. and OSMAND, A.P. Isolation of amyloid P component (protein AP) from normal serum as a calcium-dependent binding protein. Lancet (1), 1029, 1977.

84. PINTERIC, L., ASSIMEH, S.N., KELLS, D.J.C. and PAINTER, R.H. The ultrastructure of $C_{1} t$, a subcomponent of the first component of complement: an EM and ultra-centrifuge study. J. Immanol. 117, 79, 1976.

85. POWERS, I.M. and SPICER, S.S. Histochemical similarity of senile plaque amyloid to APUD-amyloid. Virchows Arch. A, 376, 107, 1977.

86. PRAS, M., SCHUBERT, M., ZUCKER-FRANKLIN, D., RIMON, A. and FRANKLIN, E.C. The characterization of soluble amyloid prepared in water. J. Clin. Invest. 47, 924, 1968.

87. REID, I.M. Corpora amylacea of the bovine mammary gland. J. Comp. Path. $82,409,1972$.

88. RIDGON, R.H. Amyloidosis: spontaneous occurrence in white pekin ducks. Am. J. Pathor. 39, 369, 1961 .

89. RIDGON, R.H. Occurrence and association of amyloid with disease in birds and mammals including man: a review. Texas Rep. Biol. Med. 32, 665, 1974.

90. ROSENTHAL, C.J. and FRANKLIN, E.C. Variation with age and disease of an amyloid A related serum component. J. Clin. Invest. 55, 746, 1975.

91. ROSENTHAL, C.J., FRANKLIN, E.C., FRANGIONE, B. and GREENSPAN, J. Isolation and partial characterization of SAA, an amyloid-related protein from human serum. $J$. Immunoz. 116, 1415, 1976.

92. RUINEN, L. personal communication, 1978.

93. SCHEINBERG, M.A., GOLDSTEIN, A.L. and CATHCART, E.S. Thymosin restores $T$ cell function and reduces the incidence of amyloid disease in caseintreated mice. J. Immunol. 116, 156, 1976.

94. SCHULTZ, R.T. Relation of Congo red birefringence to altered vascular permeability in amyloid formation. Fed. Proc. 33, 2307, 1974.

95. SCHULTZ, R.T. Role of altered vascular permeability in amyloid formation. Am. J. Pathol. 86, 321, 1977. 
96. SCHWALBE, H.P. and QUADBECK, G. Die Corpora amylacea im menschlichen Gehirn. Virchows Arch. A, 366, 305, 1975.

97. SHAKHLAMOV, V.A., BARANOV, V.N., RUKOSUEV, V.S. and KAPINUS, L.N. The role of increased vascular permeability in formation of dimorphous amyloid in the myocardium of mice. Arkh. Patol. 39, 58, 1977.

98. SHIRAHAMA, T. and COHEN, A.S. Lysosomal breakdown of amyloid fibrils by macrophages. Am. J. Pathol. 63, 463, 1971.

99. SHIRAHAMA, T. and COHEN, A.S. Intralysosomal formation of amyloid fibrils. Am. J. Pathol. 81, 101, 1975.

100. SIPE, J.D., IGNACZAK, T.F., SCOTT POLLOCK, P. and GLENNER, G.G. Amyloid fibril protein AA: purification and properties of the antigenically related serum component as determined by solid phase radioimmunoassay. J. Immonol. $116,1151,1976$.

101. SIPE, J.D., MCADAM, K.P.W.J., Torain, B.F. and POLLOCK, P.S. Isolation and structural properties of murine SAA, the acute phase serum precursor of amyloid AA. Immunol. Com. 6, 1, 1977.

102. SKINNER, M., COHEN, A.S., SHIRAHAMA, T. and CATHCART, E.S. P-component (pentagonal unit) of amyloid: isolation, characterization and sequence analysis. J. Lab. Clin. Med. 84, 604, 1974.

103. SKINNER, M., SHIRAHAMA, T., BENSON, M.D. and COHEN, A.S. Murine amyloid protein AA in casein induced experimental amyloidosis. Lab. Invest. 36, $420,1977$.

104. SKOGEN, B., NATVIG, J.B., MICHAELSEN, T.E. and ANDERS, R.F. A high molecular weight serum protein is the carrier for amyloid-related prote in SAA. Scand. J. Immonol. 6, 1363, 1977.

105. SPECKMANN, G. and LUTHER, J.W. Visceral gout and amyloidosis in a mute swan (Cygnus olor). Can. Vet. J. 15, 51, 1974.

106. STAM, F.C. and ROUKEMA, P.A. Histochemical aspects of corpora amylacea. Acta Neuropath. 25, 95, 1973.

107. STILLER, D. and KATENKAMP, D. Demonstration of orderly arranged acidic groups in amyloid by alcian blue. Histochem. 39, 163, 1974 .

108. STILLER, D. and KATENKAMP, D. Histochemistry of amyloid. Gustav Fischer, Jena, 1975.

109. TAKAHASHI, N., PAGE, D., INAGAMI, T. and TASHJIAN, A. Characterization of amyloid-associated peptides from medullary thyroid carcinoma. Fed. Proc. 36, 369, 1977.

110. TEILUM, G. Origin of amyloidosis from PAS-positive reticuloendothelial cells. In: Amy Zoidosis. E. Mandema, L. Ruinen, J.H. Scholten, A.S.

Cohen. Excerpta Medica Foundation, Amsterdam, 1968, p. 37.

111. TIKHANOVA, G.N. and CHEBYSHEV, A.P. Electron-microscopic characteristics of amyloid resorption. Bull. Exp. Bioz. Med. 80, 1384, 1975. 
112. TRAUTWEIN, G. and PRUKSARAJ, D. ther Amyloidose bei Schildkröten. Deutsch. Tierärztz. Wochenschr. 74, 184, 1967.

113. VIRCHOW, R. Uber eine im Gehirn und Rückenmark des Menschen aufgefundene Substanz mit der chemischen Reaktion der Cellulose. Virchows Arch. Path. Anat. Phys. Klin. Med. 6, 135, 268, 416, 1854.

114. WATANABE, S., JAFFE, E., POLLOCK, S., SIPE, J. and GLENNER, G.G. Amyloid AA protein. Cellular distribution and appearance. Am. J. Clin. Pathol. $67,540,1977$.

115. WESTERMARK, $P$. On the nature of the amyloid in human islets of Langerhans. Histochem. 38, 27, 1974 .

116. WESTERMARK, P., GRIMELIUS, L., POLAK, L.M., LARSSON, L.J., van NOORDEN, S., WILANDER, E. and PEARSE, A.G.E. Amyloid in polypeptide hormoneproducing tumors. Lab. Invest. 37, 212, 1977.

117. WESTERMARK, P. Amyloid of human islets of Langerhans. II. Electron microscopic analysis of isolated amyloid. Virchows Arch. A, 373, 161, 1977.

118. WESTERMARK, P., NATVIG, J.B. and JOHANSSON, B. Characterization of an amyloid fibril protein from senile cardiac amyloid. J. Exp. Med. 146, $631,1977$.

119. WOLMAN, M. Amyloid, its nature and molecular structure. Comparison of a new toluidine blue polarized light method with traditional procedures. Lab. Invest. $25,104,1971$.

120. WRIGHT, J.R., CALKINS, E. and HUMPHREY, R.L. Potassium permanganate reaction in amyloidosis. Lab. Invest. 36, 274, 1977.

121. YONKOSKY, D., CATHCART, E.S. and SCHEINBERG, M. B-cell activation and macrophage dysfunction in casein-induced experimental amyloidosis. Arthr. Rheum. 19, 831, 1976.

122. ZSCHIESCHE, W. Influence of RES stimulating and immunosuppressive agents on experimental amyloidosis in mice. In: Amy Zoidosis. E. Mandema, L. Ruinen, J.H. Scholten, A.S. Cohen. Excerpta Medica Foundation, Amsterdam, 1968, p. 327. 